\title{
The influence of socio-living conditions and health factors on the level of life satisfaction in the elderly
}

\section{Wpływ czynników socjalno-bytowych i zdrowotnych na poziom satysfakcji z życia ludzi w podeszłym wieku}

\author{
Kazimiera Zdziebło ${ }^{1,2}$, Jadwiga Maciejska³ , Jadwiga Trela-Lech ${ }^{4}$ \\ ${ }^{1}$ Department of Oncology and Oncology Nursing Care, Institute of Public Health, Faculty of Health Sciences, Jan Kochanowski University, \\ Kielce, Poland \\ Head of Department: Prof. UJK Maciej Kielar \\ ${ }^{2}$ Polish Nurses Association, Kielce, Poland \\ President of Association: Kazimiera Zdziebło PhD \\ ${ }^{3}$ County Hospital, Busko-Zdrój, Poland \\ Director of Hospital: Grzegorz Gałuszka MD, PhD \\ ${ }^{4}$ Center Psychiatry Świętokrzyskie, Morawica, Poland \\ Director of Center: Jacek Musiał MD, PhD
}

Key words: satisfaction with life, health factors, the elderly.

Słowa kluczowe: satysfakcja z życia, czynniki zdrowotne, osoby w wieku podeszłym.

\begin{abstract}
Introduction: The period of late adulthood is a period in which many actions for the purpose of summing up and evaluating the life so far are taken. One of the aspects of life which is then evaluated is its quality. Under the influence of many factors, the quality of life decreases among the elderly and thus it influences their life satisfaction level.

Aim of the research: To evaluate the influence of socio-living and health factors on the level of life satisfaction of the elderly. Material and methods: The research was conducted through a diagnostic survey, using an opinion poll technique. The applied research tool was a copyrighted questionnaire and life satisfaction scale - SWLS (the Satisfaction with Life Scale). The examined group consisted of persons in older age, benefiting from nurse care in various health facilities.

Results: The majority of those examined showed a mean rate (satisfaction with life). There are major discrepancies among the studies on the extent of influence according to such factors as housing conditions, income and professional activity. Health factors, namely suffering from multiple diseases, the chronic character of the disease, handicap and disability correlate with the feeling of satisfaction with life. The more factors - health problems, the lower is the rate of satisfaction with life.

Conclusions: The socio-living conditions to a major extent influence the evaluation of satisfaction with life of the examined persons. Health factors play a major role in the feeling of satisfaction with life. There are no major differences in the evaluation of the life lived so far between inhabitants of cities and the countryside.
\end{abstract}

\section{Streszczenie}

Wstęp: Okres późnej dorosłości to czas, w którym dokonuje się podsumowania i oceny dotychczasowego życia. Jednym z aspektów życia człowieka podlegających tej ocenie jest jego jakość. Pod wpływem wielu czynników obniża się ona u osób w wieku podeszłym, co wpływa na ich poziom satysfakcji z życia.

Cel pracy: Próba oceny wpływu czynników socjalno-bytowych i zdrowotnych na poziom satysfakcji z życia ludzi w podeszłym wieku.

Materiał i metody: Badania przeprowadzono metodą sondażu diagnostycznego przy użyciu ankiety. Wykorzystano autorski kwestionariusz ankiety oraz skalę satysfakcji z życia (the Satisfaction with Life Scale - SWLS). Grupę badaną stanowiły osoby w podeszłym wieku korzystające z opieki pielęgniarskiej w różnych placówkach ochrony zdrowia.

Wyniki: U większości badanych stwierdzono średni wskaźnik poczucia zadowolenia z życia. Istnieją duże różnice pomiędzy badanymi w zakresie wpływu takich czynników, jak: warunki mieszkaniowe, dochody oraz aktywność zawodowa. Czynniki zdrowotne, tj. wielochorobowość, przewlekły charakter choroby, niepełnosprawność i inwalidztwo, korelują z poczuciem satysfakcji z życia. Im więcej jest czynników - problemów zdrowotnych, tym mniejszy wskaźnik zadowolenia.

Wnioski: Warunki socjalno-bytowe w znacznym stopniu wpływają na ocenę satysfakcji z życia badanych osób. Czynniki zdrowotne odgrywają dużą rolę w poczuciu zadowolenia z życia. Nie ma znaczących różnic w ocenie dotychczasowego życia pomiędzy mieszkańcami miast a mieszkańcami wsi. 


\section{Introduction}

The aging process is a natural phenomenon and another stage of life, after a mature age. Speaking of old age there is a need to answer the question: what is old age and aging? It is still a phenomenon little known and not very interesting for philosophers, humanists and biologists. Krzyżanowski believes that aging is a process of reducing the efficiency of the body and it is a universal phenomenon, applying to all organisms [1].

An inseparable component of the senile period is the occurrence of many diseases and health problems. Most are chronic, and often lead to disability or full disability. The period of late adulthood is also one in which there are made a number of measures aimed at summarizing and evaluating past life. One of the aspects of human life being evaluated is the quality of life. Under the influence of certain factors, quality of life is decreasing in old age, thus affecting the level of satisfaction with life.

The attitude of man towards aging and old age is associated primarily with the state of health, activity, level and style of life and the ability to maintain self-reliance in meeting the needs of a decent living. The gaze of people on their own old age and the implementation of plans of life are very individual. The man himself decides on the image of old age as well as deciding directly on his own life. In the opinion of people a stereotype perception of the elderly as the infirm, helpless and socially useless is slowly vanishing. Socio-economic conditions in many countries, including Poland, have improved so that more and more older persons are considered as vital, manifesting great social activity and financially independent.

Owing to the improvement of sanitary conditions, housing, nutrition and the development of medicine, the quality of life of older people is steadily improving. However, the lifestyle of modern society often glorifies youth, progress, development, efficiency, cost-effectiveness, and makes it difficult or even impossible for older people to self-realize, be activity, or exercise the right to take initiatives in key areas of their life. It causes the potential threat of psychosocial aging [2].

The quality of the functioning of elderly people also depends on the implementation of psychosocial needs. They are seemingly trivial for young people, but in the everyday life of senior people play a very important role. The most important are:

1. The need for integration. Evidenced by the frequency of contact with people, isolation and loneliness, relationship with the environment, identification with the new environment and the type of relationships with close family and belonging to a social group.

2. The need for usability. It is based on a subjective assessment of own situation, such as additional employment, social activity or exercise activities for own family.
3. The need for autonomy - expresses desire for independence and self-reliance in every sphere of life. Economic independence increases the sense of security of elderly people.

4. The need for security - concerns the spatial, social and cultural conditions. Its satisfaction shows the level of usage of equipment and technological achievements, the ability to function in the wider society and in the family.

5. The need for life satisfaction - is nothing but a man's satisfaction with the location in the environment. As is known, older people badly adapt to new situations in life [3].

Knowledge of the factors affecting the living conditions of the elderly, their needs and attitudes is rightly considered to be essential in organizing the broader geriatric care, regardless of the courses of action of that care (i.e. prevention, treatment or rehabilitation). Nursing plays an important role in geriatric care.

The complexity of the health and social-living needs of an elderly ward is a major challenge for the organizers of geriatric nursing care, based on the principles of the nursing process, regardless of where the care is exercised. It should be emphasized that geriatric nursing differs from the other nursing specialties and it places emphasis on knowledge of the aging process and the interaction of health, aging and disease [4].

Knowledge of these interdependent processes as well as factors such as differences in the aging process of individuals, unusual responses to disease, treatment, and environmental conditions, multi-disease and chronic nature of the illness, disability, social and cultural attitudes towards old age [4] allows one to organize and provide geriatric care in a holistic manner. It also takes into account the particular needs of the individual.

\section{Aim of the research}

The aim of the work was to evaluate the influence of socio-living and health factors on the level of life satisfaction of the elderly.

\section{Material and methods}

The study was conducted using a diagnostic survey-questionnaire. As a research tool a questionnaire containing the author's 12 open or closed questions was used. Questions concerned socio-demographic data such as gender, age, education, profession carried out in the past and nowadays and the environment in which the respondent lives. The second group of questions concerned the housing conditions, income sources and their evaluation. The questionnaire also included questions about diseases and health problems among the respondents.

Moreover, the life satisfaction scale SWLS (The Satisfaction with Life Scale) was applied in the adaptation 
of Juczyński, which is a publicly accessible research tool for investigations of individuals and groups of adults, both healthy and sick. Assessed on a scale, SWLS life satisfaction expresses the satisfaction of respondents' own achievements and living conditions. The scale consists of the following five statements:

- in many ways my life is close to ideal;

- the conditions of my life are excellent;

- I am happy with my life;

- in my life I have achieved the most important things

that I wanted;

- if I could re-live my life, I want nothing to changed.

The respondent assesses to what extent (in the range of 1 - totally disagree to 7 - completely agree) each of above questions refers to his current life. Evaluation of five questions are summed and the overall score (from min. 5 points to max. 35 points) is the degree of satisfaction with life. The interpretation of the results should be based on the scale of sten, in which the raw score is presented in a standardized unit called "sten". Provisional Polish standards are shown in Table 1 . Results of 1-4 sten are treated as low, from 5 to 6 sten are treated as medium, and in the range of 7-10 sten are considered as high [5].

The study group consisted of 103 elderly people, using the nursing care in various health care premises such as hospital wards and specialist clinics of Regional Hospital and Outpatient Clinic General's Office in Busko-Zdrój. The study was conducted in 2012. In the questionnaire survey there took part elderly respondents over 65 years of age. These people voluntarily decided to participate in the survey.

The analysis of the data was performed using Microsoft Excel and comparing rates and numerical data from responses to the questionnaire with the results of aggregate score in the SWLS.

\section{Results}

In the group of examined people, the vast majority were women $(63.11 \%, n=65)$, while men accounted for $36.89 \%(n=38)$ (Figure 1).

Age of the respondents ranged from 65 to 88 years. In the age group 65-70 years there were $38.83 \%$ $(n=40)$ persons, and $55.34 \%(n=57)$ were persons in the range $71-80$ years. The fewest, $5.83 \%(n=6)$ persons were in the range $81-88$ years (Figure 2 ).

$29.15 \%(n=30)$ of respondents had primary education; the same group included people with basic technical education. $27.18 \%(n=28)$ of respondents had high school education and the fewest, $14.56 \%(n=15)$ of respondents, had a university degree (Figure 3 ).

In the examined group, $56.31 \%(n=58)$ were people living in rural areas, while $43.69 \%(n=45)$ were residents of a city (Figure 4).

Respondents rated their living conditions differently, ranging from very good to bad. Thus, $12.63 \%$ $(n=13)$ of respondents considered their living condi-
Table 1. Provisional Polish standards SWLS scale [5]

\begin{tabular}{|lcc|}
\hline Raw score (total score) & Sten & $\begin{array}{c}\text { Level of } \\
\text { satisfaction }\end{array}$ \\
$5-9$ & 1 & \\
$10-11$ & 2 & Low \\
$12-14$ & 3 & \\
$15-17$ & 4 & \\
$18-20$ & 5 & Medium \\
$21-23$ & 6 & \\
$24-26$ & 7 & High \\
$27-28$ & 8 & \\
$29-30$ & 9 & \\
$31-35$ & 10 & \\
\hline
\end{tabular}

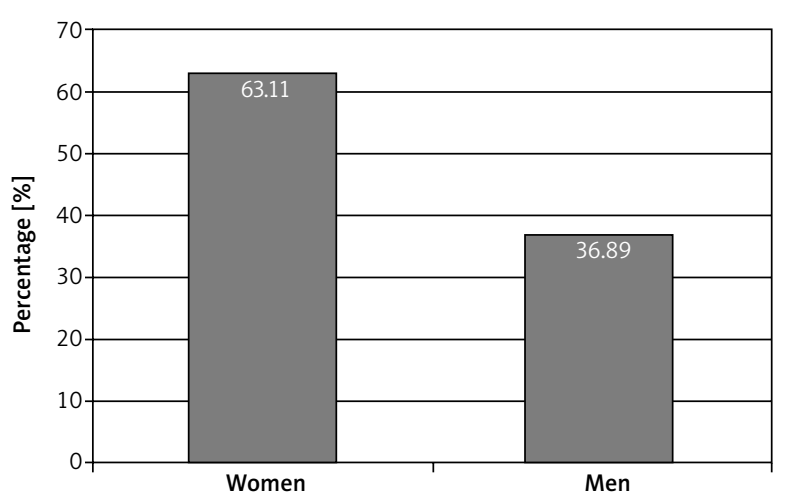

Figure 1. Gender of respondents

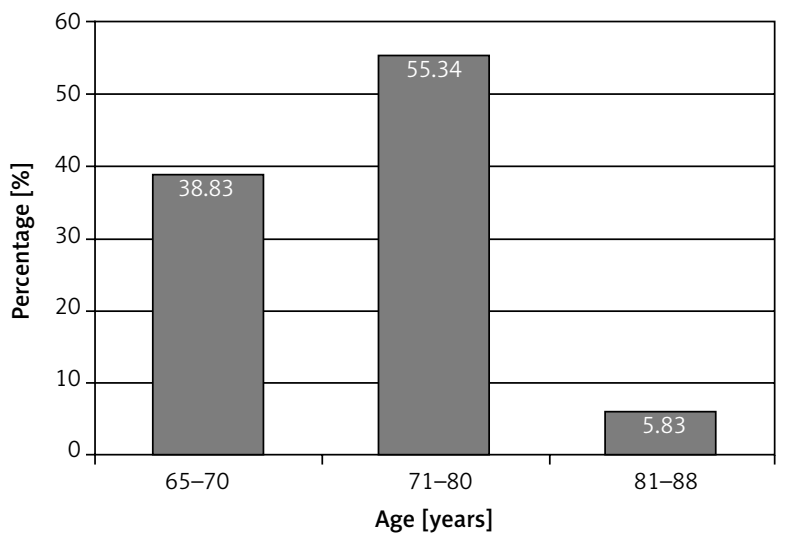

Figure 2. Age of respondents

tions as very good, $56.31 \%(n=58)$ as good. Housing conditions were rated as average by $29.13 \%(n=30)$ of respondents, and the minority of $1.94 \%(n=2)$ of respondents claimed that their living conditions were bad (Figure 5).

All the respondents stated that their primary source of income was a pension. Among this group, $11 \%(n=11)$ additionally worked; they were mostly farmers as well as teachers and medical doctors. One person $(0.98 \%)$ reported receipt of alimony. 


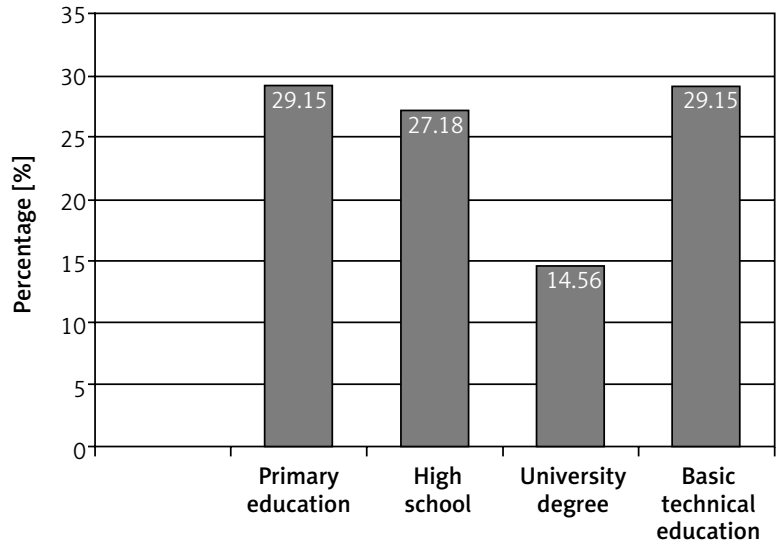

Figure 3. Education of respondents

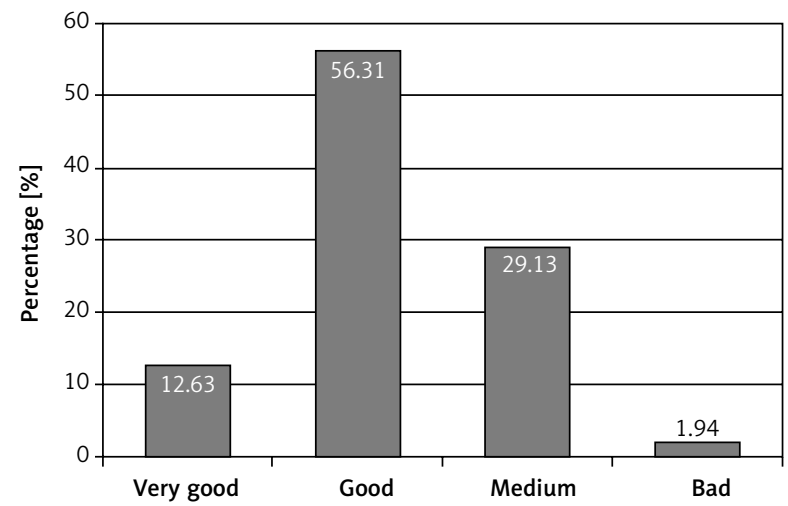

Figure 5. Assessment of housing conditions of respondents

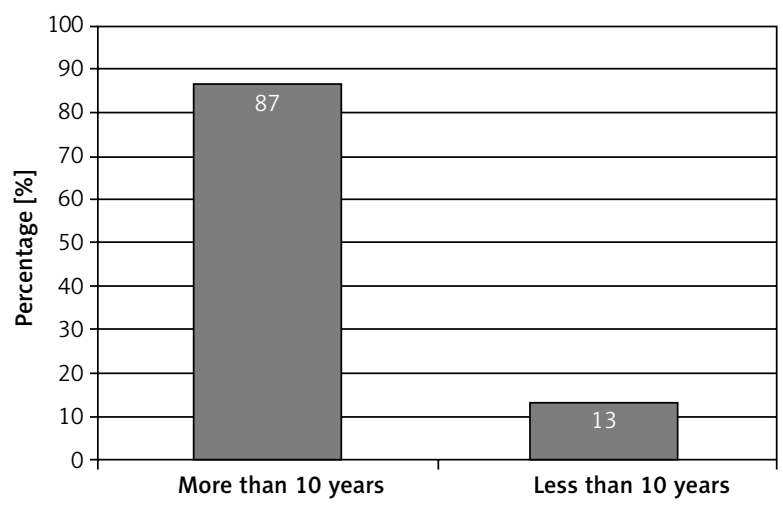

Figure 7. The duration of the disease

Respondents rated their income differently. Only $3 \%(n=3)$ of respondents rated it as very good. These were people with higher education and still professionally active. $27.18 \%(n=28)$ of respondents rated their income well, and $48.54 \%(n=50)$ stated that their income was only sufficient. There was also a group of people, representing $21 \%(n=22)$, evaluating their income as bad (Figure 6).

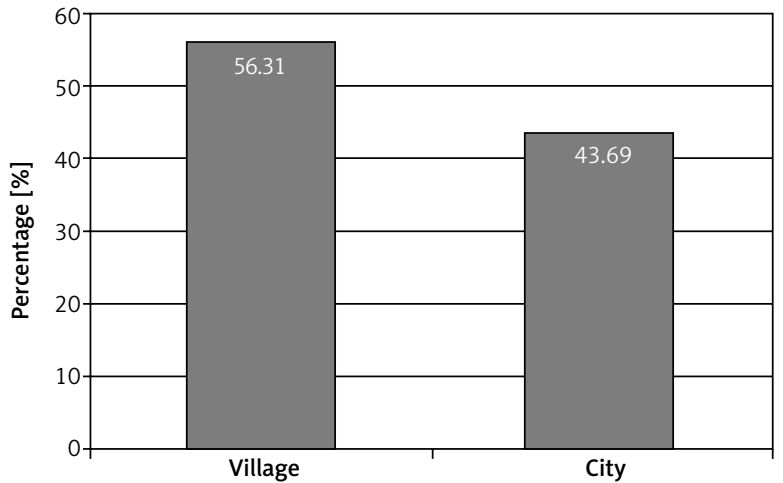

Figure 4. Place of residence of the respondents

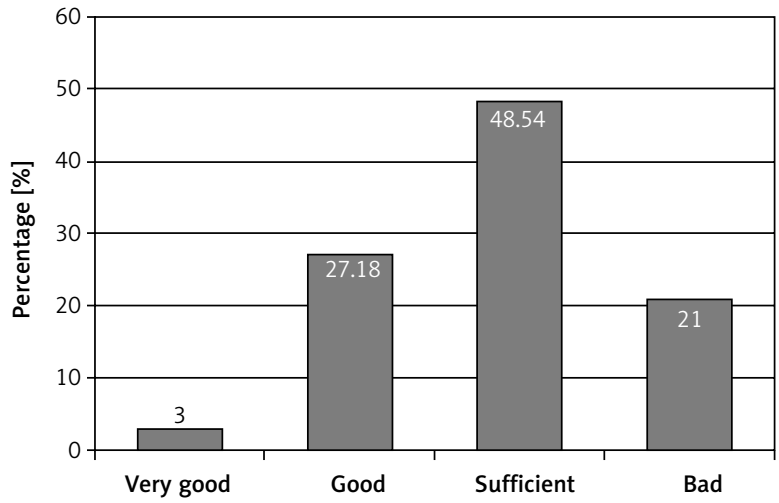

Figure 6. Rating of income

The health situation of the respondents was also analyzed. Only 1 person $(0.97 \%)$ reported that there were no health problems. In the remaining cases, regardless of age, gender, and place of residence, there were health problems that in the majority of respondents lasted more than 10 years. Eighty-seven percent $(n=89)$ of patients answered yes (Figure 7$)$.

Health problems, as they were surveyed, mainly resulted from cardiovascular disease (i.e., coronary heart disease, heart failure, hypertension, cerebrovascular disease, atherosclerosis, venous circulatory disorders). This group of diseases was reported by $61 \%(n=63)$ of respondents. A large group of $45.63 \%$ $(n=47)$ of respondents were people with diseases of the musculoskeletal system. Fourteen percent $(n=14)$ of respondents reported that they exhibited pulmonary disease. Hearing loss or amblyopia was cited by $15.53 \%(n=16)$ of respondents and metabolic disorders (diabetes, thyroid disease) by $21.36 \%(n=22)$ of respondents. $18.45 \%(n=18)$ of elderly respondents informed about urinary tract diseases, especially kidneys. The same amount of people had other illnesses such as diseases of the blood, skin, liver, stomach and intestinal cancers (Figure 8). 


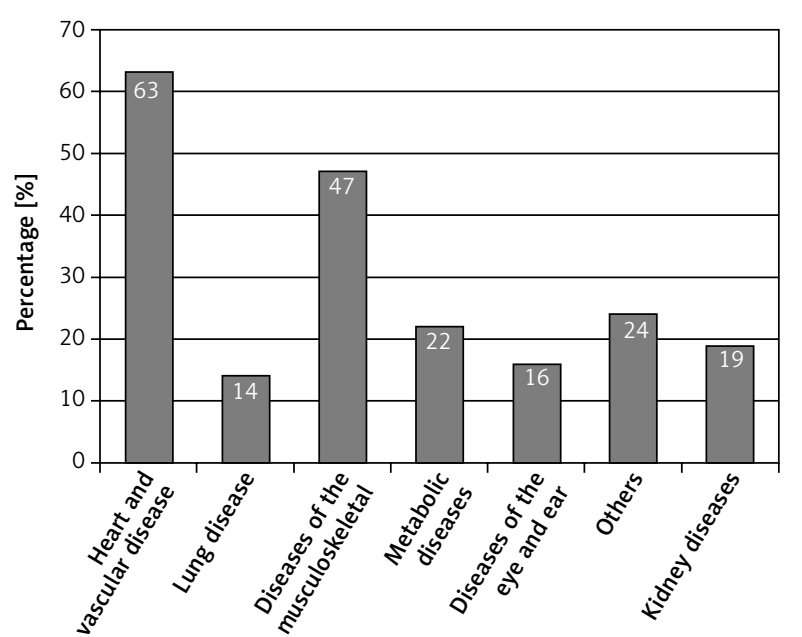

Figure 8. Type of disease of respondent (figures)

The analysis of the research shows that $84 \%$ $(n=86)$ of respondents have more than one disease and only $16 \%(n=17)$ of respondents reported one illness (Figure 9).

These diseases have different health consequences. For $44 \%(n=45)$ of respondents they are the cause of disability, and for $9.80 \%(n=10)$ of respondents they are the cause of full disability (Figure 10).

The study also assessed the degree of satisfaction with life of respondents, using the SWLS scale. It was found that the overall assessment of life satisfaction for the whole group of seniors surveyed was 22.23 points ( 6 sten), which is defined as the average score by provisional Polish standards for adults on the SWLS scale [5].

Figures for social and domestic factors (age, income, housing) and health problems were comparable to the assessment of satisfaction with life. Level of satisfaction of living in different areas varied. Thus, the age of the respondents did not significantly influence the level of satisfaction with life, because in the individual age groups, the results were comparable, i.e. from 21.70 points to 23.67 points, which corresponds with the result determined as average (6 sten). Similarly, an average level of life satisfaction of respondents was noticed as regards the place of residence factor. These results are 21.44 points for the city residents and 21.43 points for the villagers.

Different evaluations of life satisfaction occurred as a result of housing conditions of respondents. A high level of satisfaction (25.96 points, 7 sten) was reported by respondents who had very good housing conditions, while other results were at an average level and were 21.34 points for good housing conditions, 22.23 points for medium conditions, and for living in bad conditions 21.02 points.

The biggest impact on the assessment of life satisfaction was observed for health factors - their type,

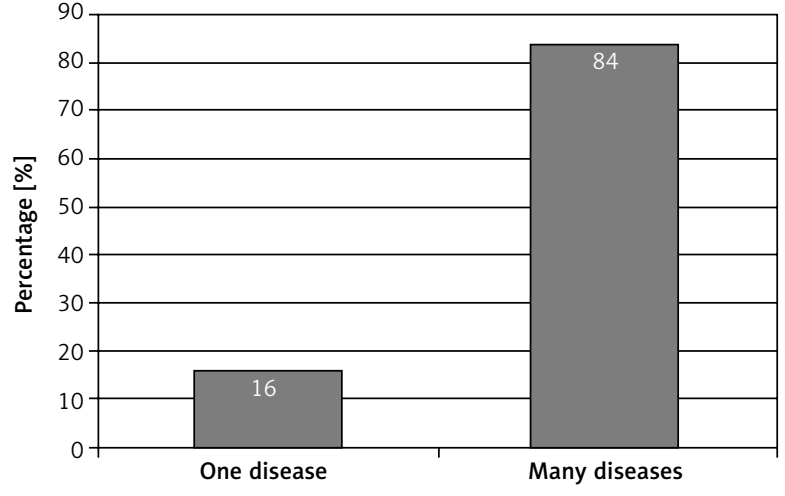

Figure 9. Number of diseases of respondents

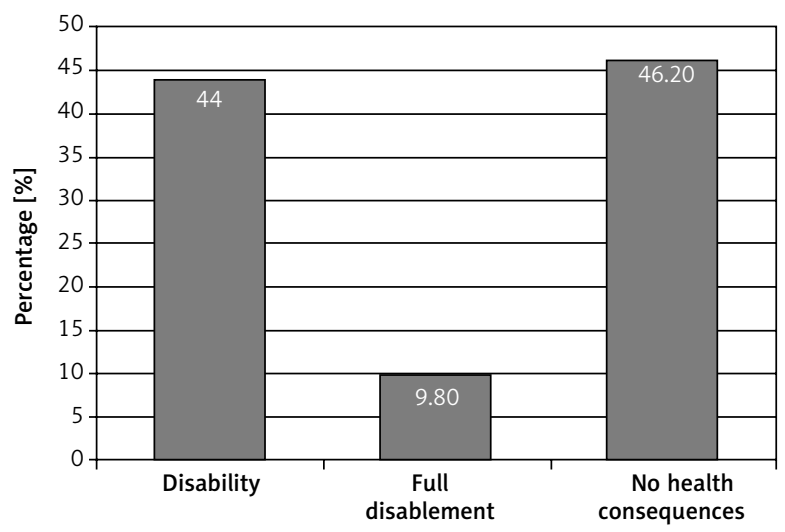

Figure 10. Health consequences of diseases of respondents

quantity and duration. Respondents who experienced cancer, blood diseases and intestinal disorders showed a low level of satisfaction with life: 17.74 points (4 sten). A very low level of life satisfaction (14.54 points, 3 sten) was calculated for respondents with kidney disease. Such a low score was attributed to the fact that in this group were patients with chronic renal failure treated with hemodialysis.

The impact of the occurrence of multiple disease, disability or full disability on the level of satisfaction with life was also analyzed. People who had the above-mentioned factors considered this sphere of life as low, for respondents who have a lot of diseases it was at the level of 17.58 points (4 sten) and 17.95 points (4 sten) for respondents whose disease caused disability or full disability (Figure 10).

\section{Discussion}

Old age is as varied as the variety of factors that influence it. Attitude to one's own old age is conditioned by many factors of a biological, psychological and socio-demographic nature. Among them we can distinguish the state of health, previous professional activity, lifestyle, marital status, relationship with 
close family, group of friends, level of education, and level of income [6].

Most of them were analyzed in this survey. An evaluation of satisfaction with life was made according to the SWLS scale in the context of socio-living and health factors. Examined socio-living factors such as age, housing, education, occupation, and source of income play a big role. For most people from the study group, they equally affect the level of satisfaction with life and are within the average results measured by the SWLS scale. But also, many of the respondents rated their social and living conditions highly (especially housing and a source of income). In this group, there was a high level of satisfaction with life ( 25.96 points - 7 sten). There were no significant differences in the assessment of life satisfaction among the citizens of towns and villages. Our study showed that the level of satisfaction for both groups was within the average results.

Assessment of the significance of living place in the context of the impact on different spheres of life of seniors, carried out by other authors, mostly differs from the results presented in this paper. Fidecki et al. [7] assessed that the place of living has an important impact on the effectiveness of elderly people. Therefore, it significantly impacts on the demand for care.

Old age also brings many diseases, especially chronic in nature, which cause numerous health problems, and particularly severe consequences in terms of disability or full disability. The comprehensive geriatric assessment of these factors affect the assessment of functional capacity. This assessment is essential for the proper care for the elderly persons.

The results of the survey indicate that the multi-disease, chronic nature of the disease, disability and full disability are the most important factors reducing the level of satisfaction with life. In addition, the more health problems, the lower is the level of satisfaction. The type of illness is very significant, leading to a substantial reduction in terms of self-satisfaction of health and psychosocial needs, resulting in the low level of satisfaction with life in the group. As an example of this, there were people with cancer, blood disease and disorders of intestines for which the index reached 17.74 points (4 sten). For people with kidney disease, mainly with chronic renal failure undergoing dialysis, the index was even lower at 14.54 points ( 3 sten). The low index of life satisfaction appeared also among the disabled and handicapped persons, which reached 17.95 points (4 sten).

A similar look at the occurrence of health problems among elderly people was presented in the research of Maniecka-Bryła and Bryła [8]. They state that happy aging is determined by many factors and the most important are the occurrence of illnesses, especially chronic forms. The most important elements of successful aging is the proper manner of mitiga- tion of illness as well as acceptance and dealing with health problems.

The research of the assessment of disease acceptance by older people living in different environments shows that older people living in a welfare home have a lower level of acceptance of disease compared with older people living in the home environment. The low level of acceptance of disease among elderly residents of welfare homes may adversely affect their level of activity and perceived quality of life. High average values of the AIS (scale of older people living at home foster positive attitudes to enable maintenance of efficiency and independence. The aim should be to create conditions which promote elderly people remaining in their home environment as long as possible, even when there is a functional deficit observed, as this is the right place to stimulate their own activity [9].

According to the results of other studies aging for many respondents means the deterioration of life (79.2\%). This applies to many aspects of life such as health, social contacts, financial situation, and participation in social life. Over 30\% of people have no funds to secure their basic needs. Age-related changes lead to a reduction of independence, loss of sense of security and inability to make independent decisions. The horizon of their own looking at the world is narrowing. There is also the reduction of intellectual abilities. The financial situation of the elderly is often complicated. The respondents have limited access to effective treatment and rehabilitation. Material and health issues often dominate among respondents. There is a lack of leisure time activities for elderly people. This is a problem particularly in rural areas. The respondents argue that the closest family should take care for elderly people. However, there are no systemic solutions that support the family in its care functions. Family care for the elderly should be encapsulated by the support services provided by non-governmental organizations and public services. Institutional care (welfare houses) should be only a last resort [10].

Maintenance of possible efficiency and a lower cut independence of the ward require a very specific approach to the patient by a multidisciplinary geriatric team (doctor, nurse, physiotherapist, psychologist, social worker, activity therapist, medical specialists and others). Comprehensive geriatric assessment is a thorough medical examination, assessment of nursing problems, psychological assessment, rehabilitation assessment, social assessment and execution of a specific set of laboratory analyses. The purpose of the assessment is to determine the functional capacity of organs, to know the health needs, psychological needs and social needs, and establish a plan of dealing with an older person in the collaborative process of diagnosis and treatment. This assessment will identify unrecognized problems of older patients, improve their functional and psychological conditions, reduce 
the burden of carers, reduce the cost of healthcare and extend life. There is also a pressing need to create a program of studies concerning the prevention of the negative effects of disease and disability and the development of gerontological education, which focuses on improving the quality of life of older people. The support system coping with the difficulties is an important moment in the active co-operation of the patient in education and prevention. Aging is accompanied by cognitive disorders that hinder the educational activities of patients (who are often: unhappy, focus on their own expectations, cope poorly with problems and have difficulties in adapting to the new conditions). It has become necessary to introduce medical students (doctors and nurses) with the issues of gerontology and geriatrics, as their contacts with elderly people require special preparation, expressed by their knowledge, skills and attitude towards aging and older people. The aging of the population and the challenges related to health and welfare require systemic and consistent actions that will enable provision of individual attention and ensure independence of wards and increase the level of satisfaction with the provided care and support for older people. Failure to provide health care prophylaxis and leave the elderly without supervision, treatment and care would be unethical [11].

Problems that accompany Polish demographic aging will therefore continue to grow and are subject to constant change. This requires isolation of respective subjects and application of proper instruments responsible for dissemination of the new model of decent life in old age. Other issues are identified now; others will be identified in 10 or 15 years when the threshold of old age exceeds the post-war baby boom generation. Skillful diagnosis and effectively performing more and more tasks will be possible only in a situation of developing good, native solutions. Therefore, while maintaining the Polish demographic, health, and cultural specificity, it is necessary to continue the dialogue with international organizations and involve the participation of representatives of all ruling levels. Equally important is dissemination of the reports prepared by the committees of the European Union and international fora in order to confront domestic needs and satisfy them in accordance with global standards and recognition of their rank as the most important condition to create a society now referred to as the "Society for all age groups" [12].

\section{Conclusions}

Our study helped to assess the intensity of action of individual socio-living conditions and health factors on the level of satisfaction of life of elderly people. Certainly, there are many other determinants of this sphere of life of seniors, which requires further research to improve knowledge of this particular group of people (from the care application point of view). Our results led to the following conclusions: socio-living conditions significantly affect the assessment of satisfaction of life of respondents. Health factors reduce the feeling of satisfaction of life and vary, depending on the type of disease, duration of disease and its effects. There are no significant differences in satisfaction of life between residents of towns and villages.

\section{References}

1. Krzyżanowski J. Psychogeriatria. Wydawnictwo Medyk, Warszawa 2004.

2. Trafiałek E. Życie na emeryturze w warunkach polskich przemian systemowych. WSP, Kielce 1998.

3. Wiechowska E. Jak zrozumieć starszą osobę? Ciało i umysł. Dostępne na: www.ochoroba.pl/artykuly/3055-jak-zrozumiec-starszą-osobę 02.11.2012.

4. Doroszkiewicz H, Bień B. Podstawowa opieka geriatryczna na świecie. Pielęgniarstwo XXI wieku 2005; 1-2: 94.

5. Juczyński Z. Narzędzia pomiaru w promocji i psychologii zdrowia. Pracownia Testów Psychologicznych, Warszawa 2009.

6. Łukomska A, Wachowska J. Seniorzy o swojej starości. Gerontol Pol 2008; 16: 51-55.

7. Fidecki W, Wysokiński M, Wrońska I. Zapotrzebowanie na opiekę pielęgniarską wśród kobiet $\mathrm{w}$ podeszłym wieku. Problemy Pielęgniarstwa 2009; 17: 281.

8. Maniecka-Bryła I, Bryła M. Poglądy osób w wieku 65-74 lat na temat pomyślnego starzenia. Gerontol Pol 2008; 16: 119-126.

9. Kaczmarczyk M. Poziom akceptacji choroby osób starszych zamieszkujących w różnych środowiskach. Studia Medyczne 2008; 12: 29-33.

10. Szpringer M, Kowalski M. Social problems of old people. Studia Medyczne 2010; 20: 19-24.

11. Zdziebło K. Współczesne zjawiska demograficzne a problemy zdrowotne starzejącego się społeczeństwa. Studia Medyczne 2008; 9: 63-69.

12. Trafiałek E, Kozieł D, Kaczmarczyk M. Starość jednostkowa i demograficzna w zadaniach gerontologii i polityki społecznej. Studia Medyczne 2009; 15: 61-67.

\section{Address for correspondence:}

Kazimiera Zdziebło PhD

The Oncology and Oncology Nursing Care

Institute of Public Heath

Faculty of Health Science

Jan Kochanowski University

al. IX Wieków Kielc 19, 25-317 Kielce, Poland

Phone: +48 698838148

E-mail: zdzieblo@wp.pl 